\title{
A Survey of Stakeholders' Views and Practices
}

\author{
Energy Policymaking in Switzerland
}

\author{
Mert Duygan, Aya Kachi, Fintan Oeri, Thiago D. Oliveira, and \\ Adrian Rinscheid
}

\begin{abstract}
Contents

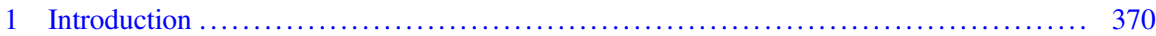

2 Energy Policymaking and Stakeholders in Switzerland ......................... 372

3 Empirical Studies on Stakeholder Involvement in Energy Policymaking ............. 373

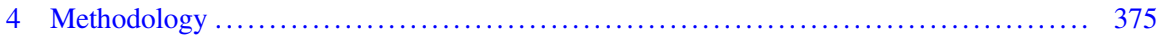

4.1 Who Are Swiss Energy Stakeholders? .................................... 375

4.2 Survey Data Collection and Sample Characteristics ....................... 376

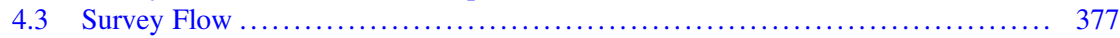

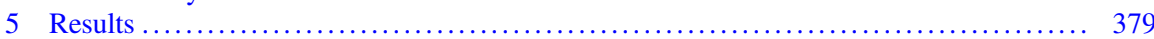

5.1 Diversity of Stakeholder Perceptions About the ES2050 Policy Targets ......... 379

5.2 Diversity in Fields of Activity and Practices Related to Policy Goal Attainment ... 382

5.3 What Types of Stakeholders Perceive ES2050 Goals as More Realistic? ........ 384

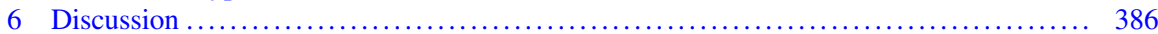

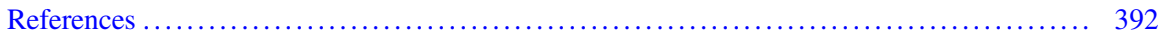

\begin{abstract}
Along with policy proposers and individual voters, key stakeholders play a crucial role in shaping the socio-political acceptance of energy policy. Understanding a broad landscape of energy stakeholders' views and practices thus should be a central theme in energy transition research. The Energy Strategy 2050 (ES2050), a sweeping energy transition policy package in Switzerland, was adopted in 2017. Concrete policy goals implied by ES2050 are yet to be implemented. Although there
\end{abstract}

Authors are listed alphabetically.

M. Duygan

University of Basel, Faculty of Business and Economics, Basel, Switzerland

Swiss Federal Institute of Aquatic Science and Technology (Eawag), Department of Environmental Social Sciences, Dübendorf, Switzerland

A. Kachi $(\varangle) \cdot$ F. Oeri $\cdot$ T. D. Oliveira

University of Basel, Faculty of Business and Economics, Basel, Switzerland

e-mail: aya.kachi@unibas.ch

A. Rinscheid

University of St. Gallen, Institute for Economy and the Environment, St. Gallen, Switzerland

(C) The Author(s) 2022

P. Hettich, A. Kachi (eds.), Swiss Energy Governance,

https://doi.org/10.1007/978-3-030-80787-0_15 
is a large body of social acceptance studies focusing on individual voters, we have a relatively scant empirical understanding of how stakeholders in this domain perceive the policy goals and how perceptions are linked to their organizational characteristics. To elucidate Swiss energy stakeholders' perceptions on key action targets implied by recent energy policies in Switzerland, we analyzed data from our original survey with 364 organizations. We examined their views on concrete policy goals related to electric mobility, deep geothermal energy, wind energy, hydropower, and planned phase-outs of renewable energy subsidies. When asked to rate how realistic these goals appear to them, the majority of the stakeholders responded negatively. Furthermore, our findings indicate that, despite the considerable diversity and the overall pessimism in their feasibility perceptions, those that consider goals to be realistic are more likely to be active in the media. This is a concerning finding as the public might receive a biased impression via the media about the level of consensus among the stakeholders, who could, at times, be seen by the public as experts on the topic.

\section{Introduction}

A lack of socio-political acceptance poses a hurdle to the pursuit of new energy policies and technologies. Apart from policymakers and individual voters, key stakeholders play a crucial role in shaping socio-political acceptance. ${ }^{1}$ Thus, understanding a broad landscape of energy stakeholders' perceptions and practices should be at the core of energy transition research.

In the context of socio-political acceptance, a large body of research has focused on the role of citizens. So-called social acceptance studies investigate determinants of public support for energy technologies, infrastructures, or policy packages. ${ }^{2}$ According to these studies, policy support does not only depend on citizens' perceptions and socio-economic statuses but also on characteristics associated with the decision-making process such as fairness and civil society participation. ${ }^{3}$ The literature also stresses the role of policy communication, e.g., communication frames and sources of information, as a potential determinant of public support. ${ }^{4}$ In this volume, too, there are several important contributions that touch upon the topic of citizens' attitude formation. ${ }^{5}$ Understanding voters' preference formation is certainly important as it can directly influence policy outputs through referenda or indirectly

\footnotetext{
${ }^{1}$ Wüstenhagen et al. (2007).

${ }^{2}$ Gross (2007); Tabi and Wüstenhagen (2017); Blumer et al. (2018); Rinscheid and Wüstenhagen (2019).

${ }^{3}$ Bidwell (2016).

${ }^{4}$ Druckman (2013); Aklin and Urpelainen (2013); Hansla (2011).

${ }^{5}$ Rinscheid and Udris (2021); Schaffer and Levis (2021).
} 
through the electoral pressure that voters exert on politicians' policy stances as the median voter theorem implies. ${ }^{6}$

However, we are all aware that it is not only individual voters' preferences that are reflected in political decisions; there are also other stakeholders. Here, we define energy stakeholders as all actors that have a stake in the public rule-making for the energy system, ${ }^{7}$ and in this chapter we specifically focus on actors that represent collective interests. There are numerous examples in energy and climate policymaking in which international and domestic lobbying by industry actors and interest groups have won the policymakers over, when the collective policy preference held by the public seemed to be the opposite of what the powerful stakeholders preferred.

To mention a few examples, the European Union (EU)'s decision in 2011 to include the aviation sector in the EU ETS was foiled by multiple international lobbying efforts despite a relatively high level of public support for the measure. ${ }^{8}$ Also in 2011, there was a contentious policy debate in Germany regarding the extension of stipulated lifespans for nuclear reactors. According to an opinion survey, voters were on average against the extension; and yet, the new policy was enacted by the governing coalition due to a small group of powerful stakeholders. ${ }^{9}$

Despite the significant influence of energy stakeholders on policymaking, surprisingly little is known about perceptions and activities of these actors. This is in part due to the inherent difficulty in collecting data on stakeholder characteristics and perceptions of policies held by the stakeholders. This challenge also applies to our understanding of energy policymaking in Switzerland, where the Energy Strategy 2050 (ES2050) — an energy policy directive that requires a fundamental realignment of energy systems - was adopted recently. From the energy governance point of view, this is clearly a deficit both for practitioners and energy researchers.

To elucidate Swiss energy stakeholders' perceptions on key policy targets implied by recent energy policies in Switzerland, we analyze data from our original survey with 364 organizations that have been involved in energy legislation during the past 3 years. We inspect their views on concrete policy goals related to electric mobility, deep geothermal energy, wind energy, hydropower, and planned phaseouts of renewable energy subsidies. We hope the chapter serves as a useful entry point towards future studies on energy stakeholders and their policy influence.

\footnotetext{
${ }^{6}$ Black (1948); Downs (1957).

${ }^{7}$ Breetz et al. (2018).

${ }^{8}$ Bernauer et al. (2014).

${ }^{9}$ Rinscheid (2015).
} 


\section{Energy Policymaking and Stakeholders in Switzerland}

In Switzerland, the revised Federal Energy Act, commonly referred to as the Energy Strategy 2050 (ES2050), has been adopted in 2017. ES2050 is a broad energy policy directive aiming to achieve the goals of phasing out nuclear energy and increasing the share of renewable energy. ${ }^{10}$ The final decision was made by public vote (referendum) on May 21, 2017. However, the implementation of each measure is expected to face a certain degree of acceptance and coordination challenges among various members of society.

This is why socio-political acceptance, in particular public acceptance, has been one of the key research topics in many branches of the SCCER (Swiss Competence Center for Energy Research) since its outset. SCCER Mobility and SCCER CREST have investigated ways to motivate the use of electric mobility by Swiss citizens. SCCER CREST also has a dedicated work package seeking paths toward effective curtailment of energy consumption based on public opinion panel surveys (Swiss Household Energy Demand Survey (SHEDS)). SCCER CREST and SCCER SoE (Supply of Electricity) have launched a new joint research program investigating public acceptance related to the expansion of hydropower (HP) and the introduction of deep geothermal energy (DGE) as ways to secure the baseload energy supply. All these efforts are meant to contribute to successful implementations of the ES2050, which aims at replacing all of Switzerland's nuclear generating capacity with renewable energy sources. Once again, many of these efforts focus on the determinants of public support for energy policy goals or technologies.

In contrast to the rich volume of studies focusing on citizens, we have a relatively thin understanding of how stakeholders in this domain perceive the various goals implied by the ES2050 scheme. This is what we will investigate in this chapter using our survey with more than 300 energy stakeholders. The adoption of new policies creates economic and ideological "winners" and "losers", which leads stakeholders to hold heterogeneous policy preferences. Wherever they can, these actors mobilize various financial and political resources to attain their policy goals. We must note, however, that their policy preferences do not automatically imply what policy goals they believe to be realistic based on their professional knowledge.

Especially in the case of ES2050 goals, there is a certain ambiguity on this. The policy process went through thorough administrative (consultation) and legislative steps between 2012 and 2017. From this dense process, one might expect that the level of consensus concerning the feasibility of the implied goals is high among the relevant energy stakeholders, who constantly engage with the topic. On the contrary, proponents and opponents of ES2050 used various narratives and evidence during the fierce political campaigns in the weeks leading to the referendum in 2017. There was ample contestation as to whether the policy package was financially too burdensome, whether the Swiss economy would benefit from it, and whether we could secure energy supply without nuclear energy. ${ }^{11}$ One might interpret such a

\footnotetext{
${ }^{10}$ Swiss Federal Office of Energy (2018a).

${ }^{11}$ See Rinscheid and Udris (2021).
} 
phenomenon as a consequence of sincerely divided perceptions by stakeholders (with a touch of exacerbation by political campaigners).

Thus, it is useful to inspect, first, whether and to what extent Swiss energy stakeholders' views vary. We answer this question by focusing on five common topics that are linked to Switzerland's energy policy: electric vehicles (EV), deep geothermal energy (DGE), wind energy, renewable energy (RE) subsidies including feed-in tariffs (FITs), and the expansion potential of hydropower (HP). In particular, we are interested in measuring the extent to which the stakeholders perceive the policy goals as realistic. Second, we examine the relationship between the actors' views and their "activeness" in politics and media. From these analyses, we will be able to identify sections of stakeholder topography that would benefit from further coordination efforts by the government in the implementation stage.

\section{Empirical Studies on Stakeholder Involvement in Energy Policymaking}

Before turning to the survey design, this section will outline how we identified key metrics that characterize energy stakeholders and their activities that are relevant in shaping policies. In doing so, we draw primarily on the political economy literature on lobbying; more concretely, the literature that addresses sources of stakeholders' success in their policy goal preference attainment.

As pointed out by prominent scholars in transitions studies, "consistently proving that special interests affect energy transition policies has turned out to be difficult". ${ }^{12}$ For this reason, many existing studies on the politics of energy transitions neither succeed in properly conceptualizing what they aim to explain nor in systematically assessing the factors that make certain actors more politically influential than others. The political influence of stakeholders is often claimed to be captured by campaign spending data or anecdotal evidence. However, actual influence on policy is rarely ascertained and measured empirically in a convincing way. ${ }^{13}$ Hence, most empirical studies that address stakeholder influence focus on other aspects, such as stakeholders' strategies (e.g., donations to politicians) and access (e.g., which politicians meet with lobbyists and how often). These might shed light on some of the ways through which actors exert political influence, but they are actually not the measures of influence. ${ }^{14}$ One notable exception is a recent study that investigated what configurations of actor endowments (resources, networks, and discursive elements) are critical for their policy influence. ${ }^{15}$

\footnotetext{
${ }^{12}$ Cherp et al. (2018), p. 181.

${ }^{13}$ Bernhagen et al. (2014).

${ }^{14}$ Mahoney (2007).

${ }^{15}$ Duygan et al. (2021a).
} 
In the remainder of the section, we will summarize how the literature has theorized various determinants of stakeholders' policy influence based on the five broad categories of actor resources that we identified. These are financial resources, organizational capacity resources, informational resources, conflict capacity resources, and network resources.

Studies using rational choice theory have demonstrated the importance of financial resources in conceptualizing lobbying as resource exchange. ${ }^{16}$ To influence political outcomes, money can be either spent directly or converted to other forms of useful resources. The motivation of direct spending is to align policymakers' incentives with those of stakeholders through direct financial contributions. ${ }^{17}$ Unlike popular views, however, empirical findings are mixed with regard to the link between actors' financial resources and their policy goal attainment. ${ }^{18}$

Stakeholders also differ in their ability to mobilize the motivational and material resources needed to establish effective instruments for the representation of their interests. ${ }^{19}$ Intuitively, one might simply suppose that the size of organizations (e.g., the number of employees and branches) has an impact on their ability to organize political interests. However, the literature shows there are more nuanced organizational characteristics that are linked to the effectiveness of stakeholders' policyrelated activities. For instance, the type of organizations' membership (individual versus collective) and organizational structure play a role. ${ }^{20} \mathrm{We}$ broadly categorize these organizational characteristics as organizational capacity resources.

Informational resources include both the level of technical knowledge and professionalization efforts. Since organizations can also convert financial resources to other essential resources such as human capital, these resources may be correlated with financial resource endowments (which should be an empirical question). However, the level of informational resources also depends on other factors-for instance, whether the organization actively invests in the professionalization of its staff and how much the organization's expertise is recognized by policymakers for other reasons than its financial resources. ${ }^{21}$ This can be measured by the stakeholder's appearance in governmental documents and hearings. Moreover, political intelligence held by the organization can be exchanged for its access to direct interactions with policymakers (inside lobbying) such as in parliamentary committees or advisory boards of regulatory bodies. ${ }^{22}$ In addition, organizations may also use informational resources to influence political outcomes through outside lobbying or constituency building, the form of lobbying that aims at the media and the public in the hope of generating support for one's own position. ${ }^{23}$

\footnotetext{
${ }^{16}$ Stigler (1971).

${ }^{17}$ Hillman and Hitt (1999).

${ }^{18}$ Walker and Rea (2014), p. 286.

${ }^{19}$ Offe and Wiesenthal (1980).

${ }^{20}$ Dür (2008).

${ }^{21}$ Hall and Deardorff (2006).

${ }^{22}$ Binderkrantz and Pedersen (2017).

${ }^{23}$ Kollman (1998); Weiler and Brändli (2015).
} 
Vote-seeking politicians are generally concerned about their (re-)election probability, which depends on the employment rate, voters' personal income, and the government's ability to use tax revenues for the provision of public services. Therefore, some states are structurally dependent on private sector profitability and this leads certain industries and groups (e.g., the coal industry in Australia) to exercise influence on policymaking via their implicit conflict capacity against the state. $^{24}$

Finally, the effectiveness of actor-specific resources in influencing policies can be amplified or suppressed by how the actors are embedded (e.g., the strategic or given position) in a network of multiple stakeholders. ${ }^{25}$ Empirical studies confirm that well-connected stakeholders that collaborate with influential actors exercise disproportionate influence on political outcomes compared to less well-connected actors with a similar endowment. ${ }^{26}$ Conceptually, we categorize various measures of actors' network embeddedness in network resources.

\section{Methodology}

To create measures for stakeholder resources that characterize their policy-related practices, we designed and implemented an original survey with organizations that are active in the energy policy domain in Switzerland. This section elaborates on the data collection methodology.

\subsection{Who Are Swiss Energy Stakeholders?}

The first question that arises upon designing such a study is the selection of relevant energy stakeholders in Switzerland. Hence, our empirical work starts with defining the targeted population in order to construct our sample for the analysis. Conceptually, stakeholders are all actors that have a stake in the public rule-making for the energy system. ${ }^{27}$ To reiterate, our aim is to analyze perceptions, activities, and actors' resources that represent collective interest. Our target group therefore is not individual voters but organizational actors such as political parties, cantonal administrations, business associations, and other organizations.

The target population was determined using participation lists of federal consultation processes on Swiss energy legislation. In addition to the fundamental realignment of Swiss energy policy (ES2050) and its consultation process

\footnotetext{
${ }^{24}$ Levy and Egan (1998), p. 342; Stutzer et al. (2021).

${ }^{25}$ Hacker and Pierson (2014); Varone et al. (2016).

${ }^{26}$ Box-Steffensmeier et al. (2013); Baumgartner et al. (2011).

${ }^{27}$ Breetz et al. (2018).
} 
from 2012 to 2013, we included the three arguably most relevant energy-related bills since 2016: Klimapolitik, ES2050 Ordinance, and StromVG ${ }^{28}$ After dropping individuals $^{29}$ and accounting for overlaps between consultations, the target group for our data collection comprised 740 organizations.

Although our aim was to approach all 740 organizations we defined as the population, identifying their contact information was anything but trivial. We were not able to contact 60 organizations from the initial sample, either because they no longer existed or because their contact details were unobtainable. This led us to invite 680 organizations to participate in our survey.

\subsection{Survey Data Collection and Sample Characteristics}

We designed and fielded an original survey in order to collect information on the characteristics, activities, and resources of stakeholders in Swiss energy policy. The pilot wave was launched in April 2019 and the main survey was fielded between May and September 2019. We communicated with the participants in German or French, depending on their contact information, and the participants were able to choose the survey language from German, French, and English. ${ }^{30}$

We conducted the pilot survey with 38 organizations, most of which were environmental NGOs and cantonal offices. After receiving their feedback, the set of included survey items remained unchanged for the main wave except for three items that were dropped after the pilot study. ${ }^{31}$ This amounts to a total of 42 survey items. After minor adjustments in the wording and the order of several items, the main wave was launched with the remaining 642 organizations. Combining the pilot and main wave, we reached out to 680 organizations.

\footnotetext{
${ }^{28}$ Klimapolitik: A consultation on Switzerland's climate policy from 2016. This included the ratification of the Paris treaty as well as the revision of the $\mathrm{CO}_{2}$ law.

ES2050 Ordinance: A consultation on the revision of 11 existing or newly introduced ordinances resulting from the first set of measures of ES2050 from 2017. The ordinance set detailed provisions in the context of the implementation of ES2050.

StromVG: A consultation on the revision of the Federal Electricity Supply Act from 2018. The revision aimed at completing the liberalization of the market by introducing the right to freely choose electricity suppliers also for small-scale consumers and households. Concurrently, it introduced measures that incentivize investments in domestic renewable energy in order to strengthen Switzerland's supply security.

${ }^{29}$ Note that individuals can also submit their opinions during consultation processes.

${ }^{30}$ Among the four official national languages of Switzerland, German and French are dominant in the political arena.

${ }^{31}$ The dropped items were on the number of business units occupied with political work, billspecific lobbying behavior and resource allocation. They covered previously assessed concepts in a narrower context. After evaluating the survey length and the value-added of responses to these items, we decided to drop them.
} 
Surveys with stakeholders are fundamentally different from surveys with individual citizens which are often used in public opinion studies in that responses require the organizations', not specific individuals', professional viewpoints. We made every effort to make the procedure transparent, and our survey was directed to people close to the competency of energy policy in order to avoid excessive communication within their organizations. To this end, we first sent personalized invitation letters with a fact sheet on the project and informed potential participants about the request to participate. Unless contact details were insufficient, no immediate action by the recipient was required. Ten days later, we emailed them personalized online survey links asking them to complete the survey within 16 days. ${ }^{32}$

After the online survey "deadline", all 463 organizations which had not explicitly indicated that they were not interested in participating and had not yet completed the survey were contacted again. This time we contacted them by mail with a printed survey along with a short reminder letter and a prepaid return envelope. ${ }^{33}$ Respondents were able to choose between responding via the original online survey link or the hardcopy.

Among the 680 organizations that we contacted, we received 364 responses. This is a remarkably high response rate of $53.5 \%$ for a stakeholder survey. About $33 \%$ of the respondents completed the survey after our reminder by mail via the hardcopy survey. Our sample mirrors the population of energy stakeholders well with respect to their organization types (Fig. 1). Our sample consists of energy businesses (30\%), business associations (23\%), non-business associations (23\%), cantonal administrations $(6 \%)$, other businesses, municipalities, and communal/cantonal associations (4\% each), and political parties and educational institutions (3\% each).

\subsection{Survey Flow}

Figure 2 summarizes the survey flow. The heterogeneous sample required the use of two different versions of the survey. Given their unique organizational form and tasks, cantonal administrations completed a version in which two items had been adapted: (i) the term "your organization" was explicitly associated with the office the respondent was working for instead of the entire cantonal administration; (ii) the item asking about the number of employees following political events was adapted to cover energy policy events only. However, the survey flow remained the same for all types of participants.

Between Welcome and Final Block are seven substantive survey blocks. The welcome page clarifies that the data will be used only for research purposes and the

\footnotetext{
${ }^{32}$ The online survey was implemented with the survey software Qualtrics.

${ }^{33}$ It was typeset in LaTeX and compiled using SDAPS, an optical mark recognition program. While minor wording changes regarding survey instruction were necessary to account for the different format, no content-related changes were made. The document amounted to 14 pages.
} 


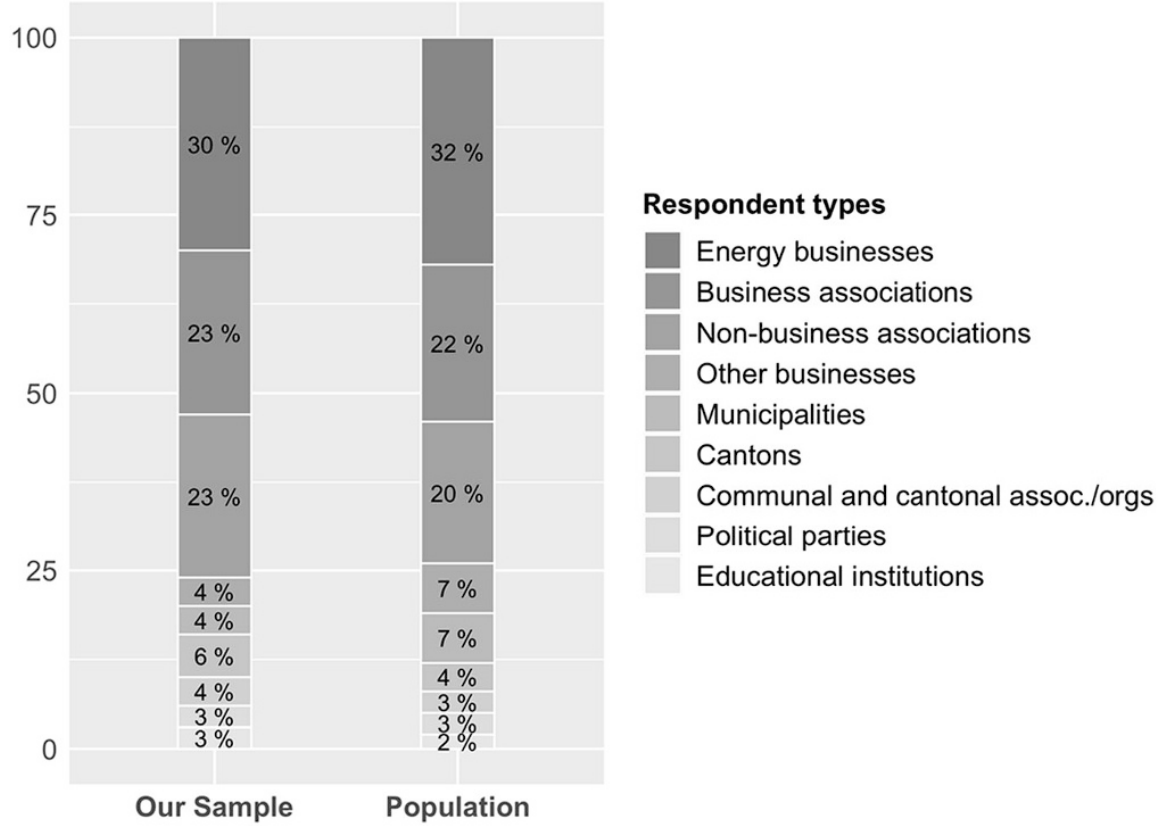

Fig. 1 Types of participating organizations $(N=364)$ : Comparison with the population of Swiss energy stakeholders

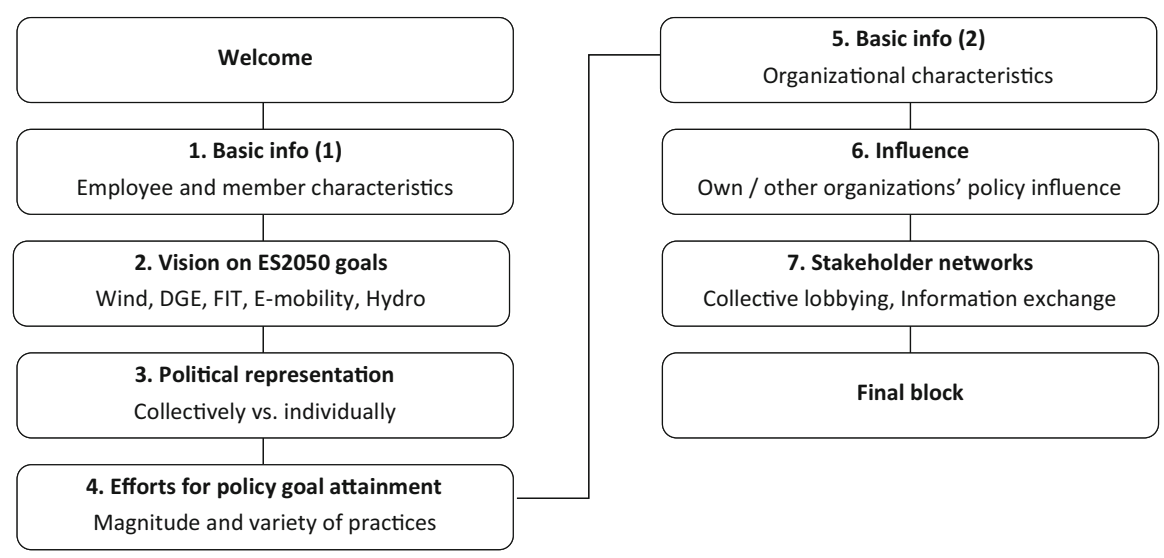

Fig. 2 Survey flow

results will be anonymized. Once respondents agree to participate, they answer questions on their organization's basic information. This block focuses on employee characteristics such as average age, education attainment, and opportunities for personnel development trainings. These questions are followed by a section that probes the organization's vision on various energy policy goals. Specifically, we ask 
whether the following goals associated with the recent energy policies look realistic from their professional point of view: new wind turbine installation, power generation capacity by deep geothermal energy, the role of feed-in tariffs, the share of electric mobility, and the expansion of hydropower generation capacity.

Next, we turn to practices employed by the organizations. In the fourth block on political representation of interests, we ask if the organization tends to take actions related to political representation alone or collectively (with other organizations) and if such collaborations come with a certain degree of adjustments ("costs") in their political goals. The fifth block, "4. Efforts for policy goal attainment", expands on related topics, focusing on the type and level of efforts exerted to follow political events or to attain policy goals. Key aspects covered in the subsequent block, "5. Basic info (2)," are the main fields of activities (e.g., sectors and types of energy production technologies), the organizational structure, and the budget.

The last two survey blocks ("6. Influence" and "7. Stakeholder networks") pose various questions about the positioning of the organization within the energy policy arena in Switzerland. First, we probe the participants' perceptions about other organizations' influence on policymaking in Switzerland as well as their assessment of their own influence on policy. Finally, we collect data on Swiss energy stakeholder networks - namely, with which other organizations the participant collaborates and/or exchanges information. The survey ends with an item asking whether the participating organization would like to receive a report based on the data. If so, then the participant should provide his or her email address. See Table 3 for the list of survey items.

\section{Results}

\subsection{Diversity of Stakeholder Perceptions About the ES2050 Policy Targets}

In this section, we inspect the Swiss energy stakeholders' views on five common topics that are linked to recent energy policies: electric vehicles (EV), deep geothermal energy (DGE), wind energy, renewable energy (RE) subsidies including feed-in tariffs (FITs), and the expansion potential of hydropower (HP). The following policy goals implied by ES2050 (Table 1) have been some of the focal points in the current policy debate.

\subsubsection{Challenges Associated with the ES2050 Targets}

We asked each participant to rate, all things considered, how realistic these targets are from the organization's point of view. Independently from their views on the feasibility, we also asked what the primary challenges associated with each goal are. 
Table 1 Goals in five energy sub-domains of Swiss energy policy

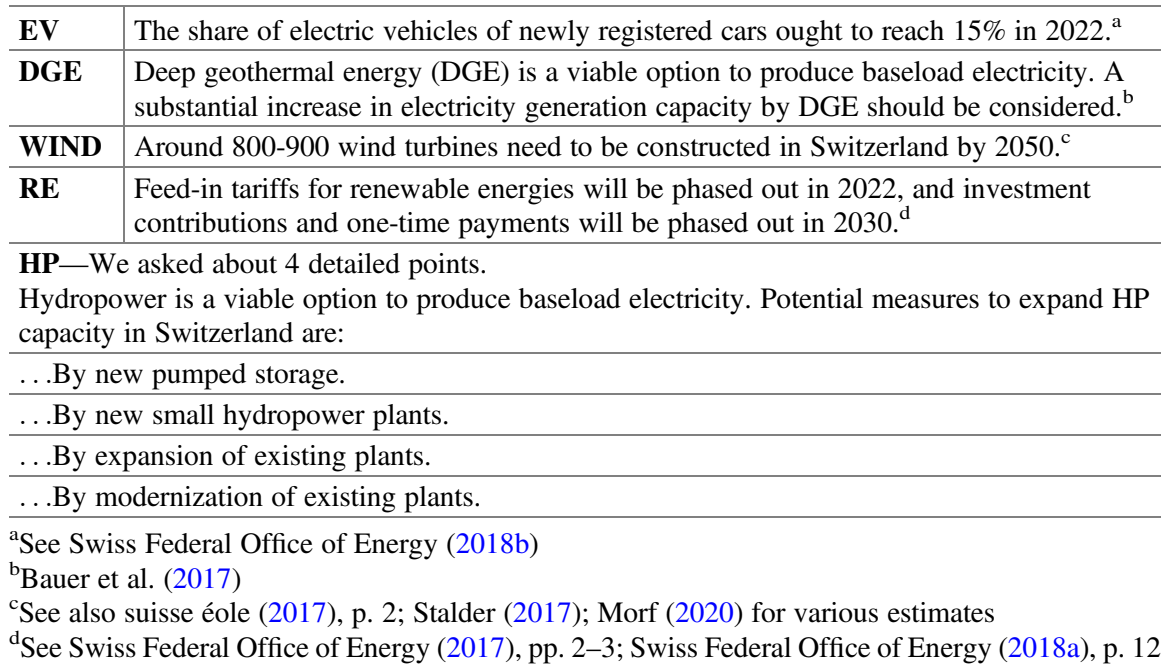

They were able to choose as many types of challenges as they wanted from the provided list.

The question about the associated challenges mostly confirmed what we already knew from previous policy debates and research. As for EV, more than half of the respondents mentioned "weak infrastructure for electric vehicles" as a barrier and nearly a third mentioned "technological maturity", "high investment costs", "information deficits of consumers", and "low acceptance of EV by consumers". Power generation by DGE is currently only in a pilot and development phase (although heating by geothermal energy has been in use); however, two cities in Switzerland (Basel and St. Gallen) had their pilot projects halted due to seismic events caused by exploratory drilling. ${ }^{34}$ The responses regarding DGE reflected these episodes-“seismic risks" (63\%), "opposition by citizens" (54\%), and "high investment costs" (49\%) were mentioned by many respondents.

Hydropower (HP) is also considered to be a potential clean source of the baseload energy supply. HP has long been a major energy source in Switzerland and currently produces approximately $60 \%$ of all domestic energy. Here, the main debate is whether an expansion of current power generating capacity by any of the four methods mentioned in Table 1 is feasible. The result confirms previous research that the opposition by interest groups (mainly environmental NGOs) is the largest barrier (mentioned by $74 \%$ of the participants).

Turning to the goals related to the so-called new renewables, the biggest challenges associated with a major installation of wind turbines are the opposition by citizens and by interest groups; more than $80 \%$ of respondents mentioned these two.

${ }^{34}$ Ejderyan et al. (2019). 
This mirrors Ebers Broughel and Wüstenhagen's contribution (in this volume) that emphasizes opposition by the local population or other stakeholders as an important factor that can lead to prohibitively high administrative risks in the implementation of wind power projects. ${ }^{35}$ Finally, we asked what options should be considered to support the expansion of RE in Switzerland against the backdrop that phase-outs of some of the RE subsidies are planned by 2022 and some more by 2030 . Half of the respondents are in favor of an extension of FITs after 2022 and nearly $40 \%$ of them are in favor of new market premium models after 2022.

\subsubsection{Divergent Views on Feasibility}

So far, on the aggregate level, our findings merely confirm mainstream views on the barriers linked to each subdomain. What is more intriguing is how divided the energy stakeholders' ratings are with regard to the feasibility of each goal. We asked whether each target summarized in Table 1 looked realistic from the organization's point of view. They could choose their responses from a Likert scale of completely unrealistic, rather unrealistic, rather realistic, and completely realistic. For the item on FITs and other subsidies, the question was phrased as "All things considered at this moment, from your organization's point of view, do you think it is realistic that the targets of the Energy Strategy 2050 will be attained in this policy environment?"

From Figs. 3 and 4, one can clearly see that the stakeholders' views are divided on many of the policy targets. When it comes to EV, the majority of them consider the target to be achievable; and yet, there are still $45 \%$ of them perceiving otherwise. There is a commonly held impression that DGE in Switzerland carries a negative legacy from the two cancelled pilot projects in Basel and St. Gallen due to seismic events. However, $38 \%$ of energy stakeholders consider this goal realistic, which is much higher than the proportion of respondents who think that wind turbine installations and the RE promotion under the planned phase-outs of RE subsidies are feasible. It is particularly noteworthy that those who hold negative perceptions about the feasibility of a large-scale wind energy installation have a strong viewmore than $25 \%$ responded "completely unrealistic". Overall, a relatively pessimistic picture looms out of Fig. 3-the majority of Swiss energy stakeholders perceive the policy targets as unrealistic.

As for HP, we asked more nuanced questions based on on-going debates. Given the gradual phase-out plan of nuclear energy, HP is considered as one of the clean energy sources that could contribute to a stable baseload. In this context, an expansion of HP generation capacity is currently considered. At the same time, there is a wide-spread view that Switzerland has exhausted potential sites for HP facilities. Against this backdrop, it is rather surprising that around $50 \%$ of the participants consider the construction of new plants to be realistic. Capacity

${ }^{35}$ Ebers Broughel and Wüstenhagen (2021). 


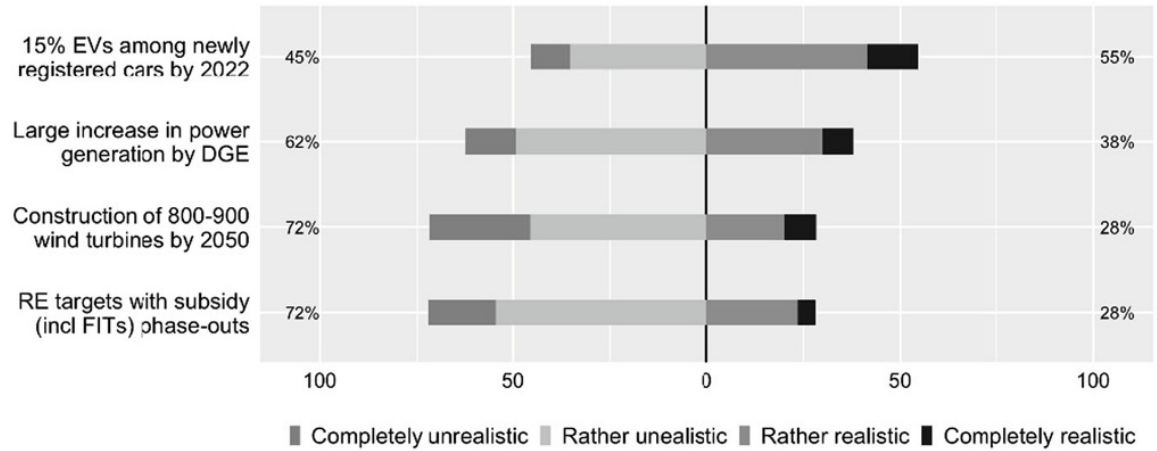

Fig. 3 "All things considered at this moment, from your organization's point of view, does this target look realistic or unrealistic?" $(\mathrm{N}=303)$

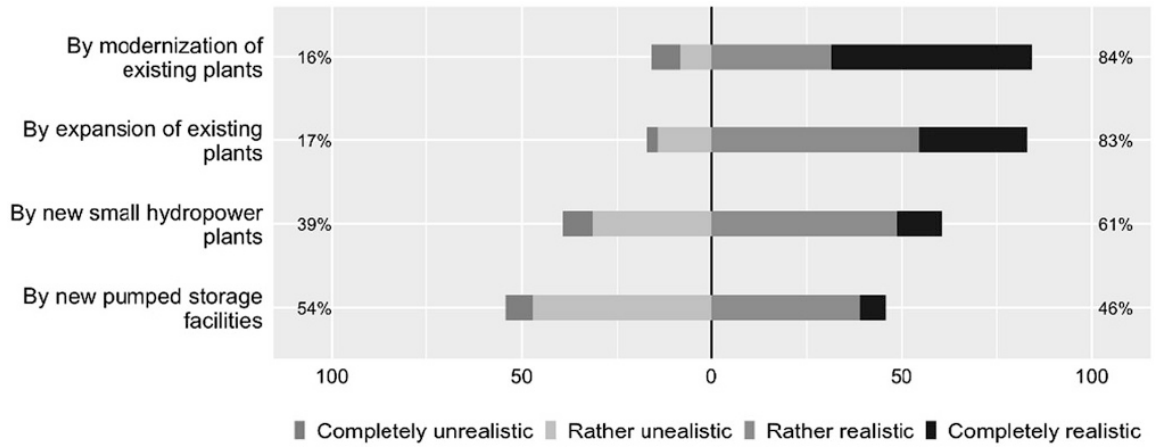

Fig. 4 "Hydropower represents an important part of the Swiss electricity generation mix. All things considered at this moment, does your organization consider the following measures to expand HP capacity in Switzerland to be realistic?" $(\mathrm{N}=304)$

expansion of existing facilities is considered to be realistic by more than $80 \%$ of the organizations.

\subsection{Diversity in Fields of Activity and Practices Related to Policy Goal Attainment}

Needless to say, these actors are diverse with respect to their fields of activity as well as their organizational characteristics. This section will give a glimpse on these aspects. According to our survey, at some point during the last 10 years 126 organizations have been active in the field related to HP, 119 in transport or mobility, 89 in wind, 54 in DGE, and 50 in nuclear. (The activity fields are not mutually exclusive.) 
In the context of political influence, we should also pay attention to how active these organizations are in politics and the mediasphere. These two arenas of stakeholder activities relate to what political economists often label as inside and outside lobbying. The former refers to actors' efforts for policy goal attainment exerted directly on policymakers, and the latter includes various channels outside of the government (such as media) through which actors mobilize the public in a way that creates electoral pressure in favor of their own policy preferences.

We assess the level of political activeness by aggregating survey items that probe whether the organization has undertaken the following seven practices over the last 10 years: (i) definition of a political strategy regarding specific legislation, (ii) communication of information and political views to policymakers/administration, (iii) informal exchange with politicians, (iv) accessing non-public parts of the national parliament building ("Wandelhalle"), (v) participation in hearings of parliamentary commissions, (vi) participation in an official expert group to draft new legislation, and (vii) preparation and publication of political opinions and position papers. This composite index may not capture certain nuances. For instance, it measures neither the intensity nor the salience of each practice directly ${ }^{36}$. However, it certainly serves as a proxy for the organization's political engagement by the breadth of the activities. The distribution of the level of political engagement in our sample has a relatively clean bell-shaped curve with a slight skew to the left. On average, organizations have employed 4.22 practices out of the seven that were mentioned above with a standard deviation of 1.8. 42 organizations demonstrated a very high level of activity by engaging in all 7 activities. Interestingly, the mean level of political activeness remains nearly the same when stakeholders that are active in the mobility, DGE, wind, and HP domain are considered separately.

To measure the stakeholders' media-related activities, we used two items that ask if the organization has pursued (i) an active involvement in media debates, including opinion articles or interviews in print media, radio, television, and (ii) communication with the public via digital media such as Facebook, Instagram, Twitter, etc. Here, the responses were even more dispersed. 122 organizations engaged in none of the media-related activities, 94 in only one type of the activities, and 96 in both. Once again, there is no significant difference in this distribution when respondents that are active in the five subdomains are analyzed separately.

Finally, in the context of stakeholders' efforts for policy goal attainment, one might associate their policy influence with the level of financial resources held by the organizations. Such an inferential analysis is beyond the scope of the present chapter; however, it might be useful to note that here, too, variation is large. Figure 5 plots the distribution of the total annual budget of the organizations (top) and their budgets for political purposes (bottom). In political purposes we include political advocacy, information brokerage, and campaign financing.

\footnotetext{
${ }^{36}$ It might not capture the scope of competence in which actors engage in these practices either (Duygan et al. 2021b).
} 


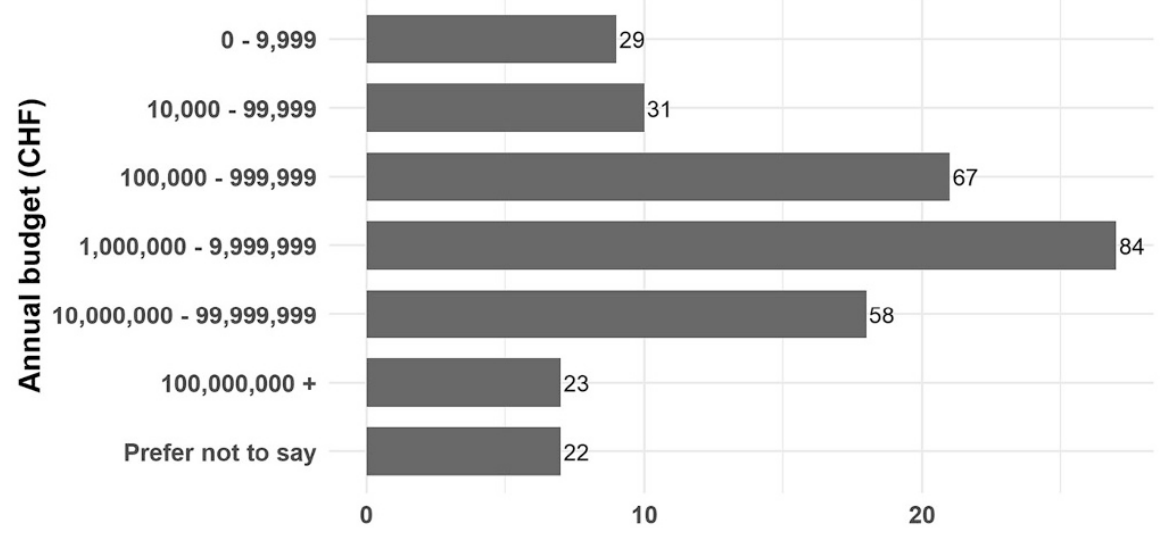

$\%$
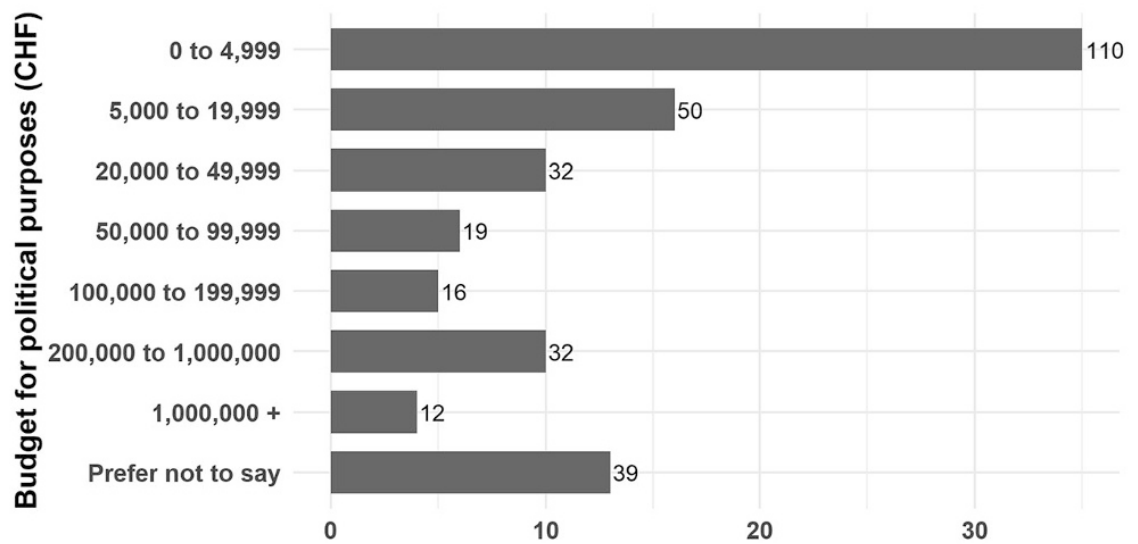

$\%$

Fig. 5 Size of the budget of Swiss energy stakeholders: Total annual budget and budget for political purposes $(\mathrm{N}=312)$

\subsection{What Types of Stakeholders Perceive ES2050 Goals as More Realistic?}

Naturally, all these observations make us wonder what explains the dramatic diversity in the stakeholders' feasibility perceptions. Are there systematic patterns in the type of actors that view a certain policy target as more realistic than others? The question deserves more thorough investigations in the future; here we will highlight a 
Table 2 Odds ratios from a logistic regression on each policy target

\begin{tabular}{|c|c|c|c|c|c|}
\hline \multicolumn{2}{|l|}{ Dependent variable } & EV & \multicolumn{2}{|l|}{ DGE } & Wind \\
\hline \multicolumn{2}{|c|}{ Active in the area of transport/mobility last $10 \mathrm{yrs}$} & 0.85 & & & \\
\hline \multicolumn{2}{|l|}{ Active in the area of DGE last 10 yrs } & & \multicolumn{2}{|l|}{1.02} & \\
\hline \multicolumn{2}{|l|}{ Active in the area of wind energy last $10 \mathrm{yrs}$} & & \multicolumn{2}{|l|}{ 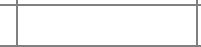 } & $0.59^{*}$ \\
\hline \multicolumn{2}{|c|}{ Active in the area of nuclear energy last $10 \mathrm{yrs}$} & 0.75 & \multicolumn{2}{|l|}{0.95} & 1.24 \\
\hline \multicolumn{2}{|l|}{ Activeness in politics } & 0.98 & \multicolumn{2}{|l|}{1.04} & 0.92 \\
\hline \multicolumn{2}{|l|}{ Activeness in media } & $1.46^{*}$ & \multicolumn{2}{|l|}{$1.36^{*}$} & $1.50^{*}$ \\
\hline \multicolumn{2}{|l|}{ Technical aspects as challenges } & $0.42^{*}$ & \multicolumn{2}{|l|}{$1.33^{*}$} & $0.42^{*}$ \\
\hline \multicolumn{2}{|c|}{ Voters, consumers, interest groups as challenges } & 0.82 & \multicolumn{2}{|l|}{1.05} & 1.14 \\
\hline \multicolumn{2}{|l|}{ Regulatory risks as challenges } & 0.86 & \multicolumn{2}{|l|}{1.27} & 0.87 \\
\hline Dependent variable $(H P)$ & Modernization & Expansion & $\begin{array}{l}\text { Small } \\
\text { HP }\end{array}$ & $\begin{array}{l}\text { Pump } \\
\text { storag }\end{array}$ & \\
\hline $\begin{array}{l}\text { Active in the area of HP energy last } \\
10 \mathrm{yrs}\end{array}$ & 0.92 & 0.89 & 0.64 & 0.97 & \\
\hline $\begin{array}{l}\text { Active in the area of nuclear energy last } \\
10 \mathrm{yrs}\end{array}$ & 1.21 & $2.33^{*}$ & 1.65 & 0.62 & \\
\hline Activeness in politics & 1.01 & 1.03 & 0.90 & 0.99 & \\
\hline Activeness in media & 0.93 & $0.68^{*}$ & 1.19 & 1.24 & \\
\hline Technical aspects as challenges & $2.04^{*}$ & 1.23 & $1.77^{*}$ & 0.83 & \\
\hline Voters, interest groups as challenges & $2.13^{*}$ & $1.72^{*}$ & 1.40 & 1.34 & \\
\hline Regulatory risks as challenges & 0.82 & 0.63 & 0.93 & 1.21 & \\
\hline
\end{tabular}

*Statistically significant estimates at the $95 \%$ confidence level

few interesting findings from our first-cut analyses. We devote this final section to reporting our first insights.

We answer these questions by studying the correlations between some of the stakeholders' characteristics and their feasibility views that are summarized in Figs. 3 and 4. More concretely, we focus on whether the organizations' feasibility assessment is linked to (1) their being active in the related energy subdomain (e.g., wind, HP, etc.), (2) how engaged they are in politics, (3) how active they are in media, and (4) what types of challenges they flagged for the policy goal in question. We categorized various challenges that the respondents marked into three groups: technological challenges (including construction and operational costs), risks associated with opposition (including voters and interest groups), ${ }^{37}$ and regulatory risks. A measure for being active in the nuclear energy domain was also included as an additional control. The dependent variable, feasibility assessment, is a 4-point Likert scale from completely unrealistic (coded as 1) to completely realistic (coded as 4).

We estimated the correlations by running an ordered logistic regression for each of the ES2050 policy targets listed in Table 1, except for the RE subsidy goal. Table 2 summarizes the results as estimated odds ratios for each covariate. Each column represents regression results for a specific policy target.

\footnotetext{
${ }^{37}$ In the analysis for EV, we included information deficits by consumers in this category.
} 
It turns out that being active in the sub-domain in question does not necessarily lead the actors to similar views on target feasibility. Only for the case of wind energy, being active in this domain systematically makes them think that the target is less realistic compared to those outside of the field. ${ }^{38}$ The organization's perceptions on feasibility are not systematically linked to their level of political engagement. However, those that are more active in the mediasphere are 1.36-1.50 times more likely to respond that the EV, DGE, and wind energy target is realistic.

One might also ask whether the organization's attention to a certain type of challenge is more strongly linked to their feasibility assessment of the policy targets. Interestingly, our results suggest that stakeholders might acknowledge the possibility of facing opposition and regulatory risks, but these assessments do not systematically lead them to claim that the target is realistic or unrealistic. On the contrary, their assessment of technical challenges seems more directly linked to their feasibility assessment. However, as for DGE and HP, those that recognize greater technical challenges are the stakeholders that tend to claim that the policy target in question is more realistic.

One finding that stands out is the perception of an HP target. With regard to the question of whether HP generation capacity can be enhanced by expanding existing facilities, actors in the nuclear energy domain are 2.3 times more likely to claim that the goal is realistic. Similarly, those that recognize civil-society opposition groups as a challenge are more likely to consider the goal realistic.

\section{Discussion}

This chapter has illustrated some of the initial findings from a large-scale energy stakeholder survey in Switzerland $(\mathrm{N}=364)$. Compared to public opinion surveys, recreuitment of participants into surveys with professional organizations is in general more challenging. In this sense, the survey data we presented here might serve as a reasonable entry point for practitioners and researchers who are interested in conducting systematic analyses on the complex links between energy policymaking and the influence of relevant stakeholders.

The discussion on the Energy Strategy 2050 began in 2011 and the policy was finally adopted after the referendum in 2017. As studies on social (voter) acceptance of energy policy goals flourish, we have seen an increasing number of insightful opinion surveys and survey experiments with population-representative samples that can identify sources of acceptance. However, we are yet to gain a systematic understanding about the landscape of energy stakeholders' views and activities around these goals. From the energy governance point of view, this is a clear deficit both for practitioners and energy researchers, as a more comprehensive understanding of the socio-political acceptance of the ES2050 and its various

\footnotetext{
${ }^{38}$ More specifically, for those active in the wind energy field, the odds of being more likely to say that the target is realistic are $40 \%$ lower.
} 
implications may help address policy risks that could inhibit the realization of its goals proactively. ${ }^{39}$

In this chapter, we addressed this gap between different sides of socio-political acceptance by illustrating the diversity of energy stakeholders' perceptions. For multiple key policy goals associated with ES2050, we investigated how realistic the actors perceived them to be. It is quite astonishing that there was no consensus about the goal feasibility for any of the ES2050 policy goals. Moreover, on the aggregate level, the sentiment is pessimistic - there are more actors who perceive the goals to be unrealistic than those who perceive them as realistic. Given this sentiment, it also makes sense that the majority of stakeholders are in favor of extending renewable energy subsidies (or similar market incentives) after 2022 when the current incentives are planned to end.

However, it was challenging to pinpoint what types of actors (or what actor characteristics) are behind the polarizing views on target feasibility. Our survey data reveal that, for the most part, being active in the same energy subdomain does not always make the actors see the feasibility in a similar way, implying that divergent views do not only exist on the aggregate level but also within the sector. Most of the surveyed organizations actively engage in multiple practices to represent their political interests, too. Again, the degree of political activeness was not systematically linked to their feasibility perceptions either on the optimistic or the pessimistic side, implying that coordination efforts by policymakers are required at every end of the stakeholders' attitude spectrum.

One concerning element of our findings is that, despite the high level of diversity and the overall pessimistic views on policy goal feasibility, those that perceive the goals to be realistic are more likely to undertake media-related strategies at the same time. The public might receive a biased impression about the level of consensus among the stakeholders. A more detailed classification of the sources of divergent stakeholder views seems to be a fruitful avenue for future research. A systematic investigation of stakeholders' views and perceptions, as conducted in this study, may also allow us to strengthen integrative efforts further. A good example along this line might be the "Energy Transition Preparedness Index" proposed by Bürer et al.: ${ }^{40}$ They highlight crucial elements of the energy-society system area that determines the pace of implementing energy system change.

Given that there is already a set of defined policy goals under the Energy Strategy 2050, perhaps one of the biggest challenges for politicians and the Federal Administration during the next years is to come up with effective modes of communication with their own citizens that help them make sense of the divergent feasibility perceptions that appear to exist "even" among the actors who are involved in energy topics on a daily-basis. This is indeed a hefty task for the government. Such communication by the government needs to be transparent to citizens, fair to diverse stakeholders, and neutral given its public function in order to make sure that the government is not mistaken as a user of manipulative narratives.

\footnotetext{
${ }^{39}$ Ebers Broughel and Wüstenhagen (2021).

${ }^{40}$ Bürer et al. (2021).
} 
Table 3 List of items included in the Survey "Diversity of Swiss Energy Stakeholders" (June 2019)

\begin{tabular}{l|l}
\hline Item & Question \\
\hline \multicolumn{1}{l}{ Welcome } \\
\hline \multicolumn{1}{l}{ Welcome and thank you for your participation... } \\
\hline 1. Basic information (1) \\
\hline & $\begin{array}{l}\text { In the first part we would like to ask you some questions about the employees and, if } \\
\text { applicable, about members of your organization. If you do not know the exact answers, } \\
\text { we ask you to estimate as accurately as possible. }\end{array}$ \\
\hline Q5 & $\begin{array}{l}\text { How many paid employees does your organization have? Please provide your details in } \\
\text { full-time equivalents. If you do not know the exact number, please guess. }\end{array}$ \\
\hline Q6 & $\begin{array}{l}\text { How many unpaid employees does your organization have? Please provide your details } \\
\text { in full-time equivalents. If you do not know the exact number, please guess. }\end{array}$ \\
\hline Q7 & $\begin{array}{l}\text { How old are the employees of your organization on average? If you do not know the } \\
\text { answer, please guess. } \\
\text { degree? If you do not know the answer, please guess. }\end{array}$ \\
\hline Q8 & $\begin{array}{l}\text { How often do employees of your organization participate in multi-day personnel devel- } \\
\text { opment activities on average (e.g., internal training, professional development, executive } \\
\text { education)? If you do not know the answer, please guess. }\end{array}$ \\
\hline Q10 & $\begin{array}{l}\text { So-called "member organizations" can have both individuals (e.g., in the case of political } \\
\text { parties) and/or other organizations (e.g., in the case of associations) as members. In } \\
\text { non-member organizations (e.g., companies) there are no members, only employees or } \\
\text { involved parties. } \\
\text { How many members of each type does your organization have? Please choose one entry } \\
\text { for each member type. In both drop down lists, there is also the option "None". If you do } \\
\text { not know the exact numbers, please guess. } \\
\text { (Matrix Question) }\end{array}$ \\
\hline
\end{tabular}

2. Vision on ES2050 goals

Q19 According to the Energy Strategy 2050, around 800-900 wind turbines need to be constructed in Switzerland by 2050. All things considered at this moment, from your organization's point of view, does this target look realistic or unrealistic?

Q20 Regardless of your answer above, which of the following do you see as the biggest challenges to achieve this goal? (multiple answers possible)

Q22 According to the Energy Strategy 2050, deep geothermal energy (DGE) is a viable option to produce baseload electricity. All things considered at this moment, from your organization's point of view, does a substantial increase in electricity generation capacity by DGE look realistic or more unrealistic?

Q23 Regardless of your answer above, which of the following do you see as the biggest challenges for an increase of deep geothermal energy? (multiple answers possible)

Q25 According to the Energy Strategy 2050, feed-in tariffs for renewable energies will be phased out in 2022, and investment contributions and one-time payments will be phased out in 2030. All things considered at this moment, from your organization's point of view, do you think it is realistic that the targets of the Energy Strategy 2050 will be attained in this policy environment?

Q26 Regardless of your answer above, which of the following options should be considered to support the expansion of renewable energies in Switzerland? (multiple answers possible)

Q28 According to the recently published roadmap for the promotion of electric mobility, the share of electric vehicles of newly registered cars ought to reach 15 percent in 2022. All things considered at this moment, from your organization's point of view, does this target look realistic or unrealistic? 
Table 3 (continued)

\begin{tabular}{l|l}
\hline Item & Question \\
\hline Q29 & $\begin{array}{l}\text { Regardless of your answer above, which of the following do you see as the biggest } \\
\text { challenges to reach this goal? (multiple answers possible) }\end{array}$ \\
\hline Q31 & $\begin{array}{l}\text { Hydropower represents an important part of the Swiss electricity generation mix. All } \\
\text { things considered at this moment, does your organization consider the following mea- } \\
\text { sures to expand HP capacity in Switzerland to be realistic? (please answer for each } \\
\text { measure: By new pumped storage, by new small hydropower plants, by expansion of } \\
\text { existing plants, by modernization of existing plants.) (Matrix Question) }\end{array}$ \\
\hline Q32 & $\begin{array}{l}\text { Regardless of your answer above, which of the following do you see as the biggest } \\
\text { challenges for the expansion of hydropower generation capacity? (multiple answers } \\
\text { possible) }\end{array}$ \\
\hline
\end{tabular}

3. Political representation of interests-Collectively or individually

This block addresses the topic of political representation of interests. It can occur in different forms. We speak of interest representation as a collective when two or more actors agree on political positions and represent them together. This does not preclude a simultaneous representation of interests as an individual organization, without collusion with others. (by definition, membership organizations always act collectively. So here, interest representation as a collective is defined as activities conducted with other organizations that are not members of your organization. On the other hand, representing interests as a single organization means that there is no consultation with organizations that are not members of your organization.)

Q35 When you think about Swiss energy policy in general: has your organization undertaken the following activities as a collective and/or as an individual organization over the last 10 years? (1) Definition of a political strategy regarding specific legislation. (2) Communication of information and political views to policy makers and/or administration.

(3) Financial support of politicians. (4) Funding of institutions (e.g., political committees, parties) and/or activities (e.g., research). (5) Thematization in the public sphere (e.g., media contributions, signatures collection) (Matrix Question)

Q36 To what extent do you agree or disagree with the following statement? In Swiss energy policy, our organization is, in principle, willing to adjust its political demands, if this is necessary to enable collaboration with other organizations.

Q38 To what extent do you agree or disagree with the following statement with regard to the policy process of the ES2050?

My organization would have had to adapt its political demands to be able to cooperate (more closely) with other organizations.

\begin{tabular}{l|l}
\hline 4. Efforts for policy goal attainment \\
\hline & $\begin{array}{l}\text { The following part of the questionnaire deals with the question of how your organization } \\
\text { perceives its opportunities to represent its interests. }\end{array}$ \\
\hline Q48 & How important is political interest representation for your organization? \\
\hline Q50 & $\begin{array}{l}\text { Please think about a typical legislative process of national energy policy, which con- } \\
\text { cludes in a referendum. What proportion of time and financial resources does your } \\
\text { organization devote to different phases within such a legislative process? Please select the } \\
\text { shares so they add up to a total of 100\%. }\end{array}$ \\
\hline Q52 & $\begin{array}{l}\text { Is your organization competing with other organizations to recruit new members, raise } \\
\text { income through donations, or secure funding? }\end{array}$ \\
$\begin{array}{l}\text { Has your organization pursued the following activities during the last 10 years? (Multiple } \\
\text { answers possible) (1) Informal exchange with politicians. (2) Mandating other organi- } \\
\text { zations or experts to follow the political events or actively represent interests of the } \\
\text { organization. (3) Accessing non-public parts of the national parliament building }\end{array}$ \\
\hline
\end{tabular}


Table 3 (continued)

\begin{tabular}{|c|c|}
\hline \multicolumn{2}{|l|}{ Item } \\
\hline & $\begin{array}{l}\text { (Wandelhalle). (4) Participation in hearings of parliamentary commissions. (5) Partici- } \\
\text { pation in an official working/expert group to draft new legislation. (6) Preparation and } \\
\text { publication of political opinions and position papers. (7) Financing or conducting } \\
\text { research. (8) Active involvement in media debates (e.g., opinion articles or interviews in } \\
\text { print media, radio, television, etc.). (9) Communication with the public via digital media } \\
\text { (e.g., Facebook, Instagram, Twitter, etc.). (10) Organization of expert conferences and/or } \\
\text { public debates. (11) Funding of political advertising. (12) Funding and/or collection of } \\
\text { signatures. (13) Demonstration call. (14) Other }\end{array}$ \\
\hline Q53 & $\begin{array}{l}\text { Please indicate how many employees in your organization are commissioned to follow } \\
\text { political events in general (not only energy specific) or actively represent interests of the } \\
\text { organization (in full-time equivalents). If you do not know the exact answer, we ask you } \\
\text { to estimate as accurately as possible. }\end{array}$ \\
\hline \multicolumn{2}{|c|}{ 5. Basic information (2) } \\
\hline & $\begin{array}{l}\text { In the following penultimate part we ask you to answer a few questions about your } \\
\text { organization in general. }\end{array}$ \\
\hline Q56 & $\begin{array}{l}\text { During the last } 10 \text { years, in which areas was your organization at least at some point } \\
\text { active? (1) Hydropower. (2) Nuclear energy. (3) Solar energy. (4) Wind energy. (5) Deep } \\
\text { geothermal energy. (6) Other energy production. (7) Energy efficiency. (8) Trade of } \\
\text { electricity. (9) Natural science research on energy. (10) Economic modeling research on } \\
\text { Energy. (11) Social science research on energy. (12) Consumer information. } \\
\text { (13) Transport/mobility. (14) International economic cooperation and development. } \\
\text { (15) Other (Multiple answers possible.) }\end{array}$ \\
\hline Q57 & In which year was your organization founded? \\
\hline Q58 & How many regional/local branches does your organization have? \\
\hline Q60 & $\begin{array}{l}\text { Do representatives of these local branches have a say in your organization's policy stance } \\
\text { on issues of national interest, such as the ES2050?* } \\
\text { (*This question is shown if the response category (1) of Q58 was not selected.) }\end{array}$ \\
\hline Q61 & $\begin{array}{l}\text { Organizations can make decisions in different ways, such as unanimity among members } \\
\text { or board members, or other voting procedures. } \\
\text { Please indicate what kind of decision-making is mainly used for important decisions in } \\
\text { your organization. }\end{array}$ \\
\hline Q62 & What sources of funding are relevant to your organization? (Multiple answers possible) \\
\hline Q63 & $\begin{array}{l}\text { What is the annual budget of your organization? If you do not know the answer, please } \\
\text { guess. }\end{array}$ \\
\hline Q65 & $\begin{array}{l}\text { You have clicked that you do not want to provide any details about the annual budget of } \\
\text { your organization. We would like to point out once again that your information is treated } \\
\text { absolutely confidentially and in publications conclusions with regard to your organization } \\
\text { are in no way possible.By clicking on your budget category, you would provide infor- } \\
\text { mation that is central to our research results. Of course, if you do not want to provide any } \\
\text { information, we respect this.* } \\
(* \text { This question is shown if the response category of Q63 }=(9999))\end{array}$ \\
\hline Q66 & $\begin{array}{l}\text { What is the annual budget of your organization for political purposes (e.g., for political } \\
\text { advocacy, information brokerage, campaign financing, etc.)? If you do not know the } \\
\text { answer, please guess. }\end{array}$ \\
\hline Q68 & $\begin{array}{l}\text { You have clicked that you do not want to provide any information about your organiza- } \\
\text { tion's annual political budget. We would like to point out once again that your informa- } \\
\text { tion is treated absolutely confidentially and in publications conclusions with regard to } \\
\text { your organization are in no way possible. }\end{array}$ \\
\hline
\end{tabular}


Table 3 (continued)

\begin{tabular}{|c|c|}
\hline Item & Question \\
\hline & $\begin{array}{l}\text { By clicking on your budget category, you would provide information that is central to our } \\
\text { research results. Of course, if you do not want to provide any information, we respect this. } \\
* \text { (*This question is shown if the response category of Q66 }=(9999))\end{array}$ \\
\hline Q69 & What position do you hold in your organization? \\
\hline Q70 & How many years have you been working for your organization? \\
\hline \multicolumn{2}{|c|}{ 6. Influence } \\
\hline Q12 & $\begin{array}{l}\text { The final questions relate to your organization in the context of Swiss energy policy. In } \\
\text { the following, reference will always be made to other organizations. The term "organi- } \\
\text { zation" refers to all types of stakeholders in energy policy, such as energy companies, } \\
\text { NGOs, political parties, umbrella organizations or even cantons and municipalities. }\end{array}$ \\
\hline Q13 & $\begin{array}{l}\text { Please list those organizations that you consider to be influential in Swiss energy policy } \\
\text { of the last } 10 \text { years. Please also list your own organization or individual members, if you } \\
\text { count them among the influential organizations. (You can list as many organizations as } \\
\text { you want. Additional text entry boxes will automatically appear. The order does not } \\
\text { matter.) }\end{array}$ \\
\hline Q14 & $\begin{array}{l}\text { Listed are the organizations you mentioned that have influence on Swiss energy policy. } \\
\text { Please choose the most influential organizations; on the one hand, with respect to Swiss } \\
\text { energy policy in general and on the other hand, with respect to the Energy Strategy } \\
\mathbf{2 0 5 0} \text { (ES2050) specifically. In both cases you can choose up to five organizations; } \\
\text { however, it is also possible to choose fewer.Energy strategy } 2050 \text { refers to new Energy } \\
\text { Act, which was drafted by the Federal Council in } 2011 / 2012 \text { and submitted to consulta- } \\
\text { tion at the end of } 2012 \text {. Between } 2013 \text { and } 2016 \text {, the parliament discussed the law and the } \\
\text { Swiss electorate approved it in } 2017 \text {. } \\
\text { (Carry Forward Entered Choices-Entered text from "Q13") } \\
\text { (Matrix Question) }\end{array}$ \\
\hline Q16 & Please assess the influence of your organization on Swiss energy policy. \\
\hline \multicolumn{2}{|c|}{ 7. Stakeholder networks } \\
\hline Q42 & $\begin{array}{l}\text { As a reminder, collective representation of interests is defined as activities in which two or } \\
\text { more actors agree on political positions, which are represented in consultation with each } \\
\text { other. } \\
\text { Please list those organizations with which your organization has represented its interests } \\
\text { collectively in legislative processes of Swiss energy policy over the last } 10 \text { years. (You } \\
\text { can list as many organizations as you want. Additional text entry boxes will automatically } \\
\text { appear. Please list only those partners who are not members of your organization. The } \\
\text { order does not matter.) }\end{array}$ \\
\hline Q44 & $\begin{array}{l}\text { Scientific, technical and political information plays an important role in energy policy. } \\
\text { With which organization do you exchange such information with respect to the Swiss } \\
\text { energy policy of the last } 10 \text { years? } \\
\text { Below you can find those organizations with which your organization has represented } \\
\text { interests in the collective in the past. Please indicate those organizations in the list with } \\
\text { which you not only represented interests collectively but also exchanged information. } \\
\text { (Carry Forward Entered Choices-Entered text from "Q42") }\end{array}$ \\
\hline Q45 & $\begin{array}{l}\text { However, information can also be exchanged with organizations without representing } \\
\text { interests together. Such information may be exchanged between like-minded organiza- } \\
\text { tions as well as with representatives of the counterparty. } \\
\text { Please list additional organizations with which your organization exchanged information } \\
\text { in the context of Swiss energy policy of the last } 10 \text { years. (You can list as many actors as } \\
\text { you want. Additional text entry boxes will automatically appear. Please list only those } \\
\text { partners who are not members of your organization. The order does not matter.) }\end{array}$ \\
\hline
\end{tabular}


Table 3 (continued)

\begin{tabular}{l|l}
\hline Item & Question \\
\hline Final block \\
\hline Q72 & $\begin{array}{l}\text { You have the opportunity to be informed about the results of our analysis. If you would } \\
\text { like to receive such a scientific report, please enter your email address here. }\end{array}$ \\
\hline Q73 & Do you have any further comments? \\
\hline & $\begin{array}{l}\text { You have reached the end of the survey. Please click on "Submit" to complete the survey. } \\
\text { Thank you very much for your participation! }\end{array}$ \\
\hline
\end{tabular}

\section{References}

Aklin M, Urpelainen J (2013) Debating clean energy: frames, counter frames, and audiences. Glob Environ Change 23(5):1225-1232

Bauer C, Hirschberg S, Bauerle Y, Biollaz S, Calbry-Muzyka A, Cox B, Heck T, Lehnert M, Meier A, Prasser H-M, Schenler W, Treyer K, Vogel F, Wieckert H, Zhang X, Zimmerman M, Burg V, Bowman G, Erni M, Saar M, Tran M (2017) Potentials, costs and environmental assessment of electricity generation technologies. Technical report for the Swiss Federal Office of Energy. Paul Scherrer Institute, Bern

Baumgartner FR, Larsen-Price HA, Leech BL, Rutledge P (2011) Congressional and presidential effects on the demand for lobbying. Polit Res Q 64(1):3-16. https://doi.org/10.1177/ 1065912909343578

Bernauer T, Gampfer R, Kachi A (2014) European unilateralism and involuntary burden-sharing in global climate politics: a public opinion perspective from the other side. Eur Union Polit 15 (1):132-151. https://doi.org/10.1177/1465116513496878

Bernhagen P, Dür A, Marshall D (2014) Measuring lobbying success spatially. Interest Groups Adv 3(2):202-218. https://doi.org/10.1057/iga.2014.13

Bidwell D (2016) Thinking through participation in renewable energy decisions. Nat Energy 1 (5):1-4. https://doi.org/10.1038/NENERGY.2016.51

Binderkrantz AS, Pedersen HH (2017) What is access? A discussion of the definition and measurement of interest group access. Eur Polit Sci 16:306-321

Black D (1948) On the rationale of group decision-making. J Polit Econ 56:23-34. Available at https://www.journals.uchicago.edu

Blumer YB, Braunreiter L, Kachi A, Lordan-Perret R, Oeri F (2018) A two-level analysis of public support: exploring the role of beliefs in opinions about the Swiss energy strategy. Energy Res Soc Sci 43:109-118

Box-Steffensmeier JM, Christenson DP, Hitt MP (2013) Quality over quantity: amici influence and judicial decision making. Am Polit Sci Rev 107(3):446-460. https://doi.org/10.1017/ S000305541300021X

Breetz H, Mildenberger M, Stokes L (2018) The political logics of clean energy transitions. Bus Polit 20(4):492-522

Bürer M, de Lapparent M, Capezzali M, Carpita M (2021) Governance drivers and barriers for business model transformation. In: Hettich P, Kachi A (eds) Swiss energy governance. Springer, New York

Cherp A, Vinichenko V, Jewell J, Brutschin E, Sovacool B (2018) Integrating techno-economic, socio-technical and political perspectives on national energy transitions: a meta-theoretical framework. Energy Res Soc Sci 37:175-190

Downs A (1957) An economic theory of political action in a democracy. J Polit Econ 65 (2):135-150. Available at https://www.journals.uchicago.edu

Druckman JN (2013) Public opinion: stunted policy support. Nat Clim Chang 3(7):617-617. https://doi.org/10.1038/nclimate1939 
Dür A (2008) Interest groups in the European Union: how powerful are they? West Eur Polit 31 (6):1212-1230. https://doi.org/10.1080/01402380802372662

Duygan M, Stauffacher M, Meylan G (2021a) What constitutes agency? Determinants of actors' influence on formal institutions in Swiss waste management. Technol Forecast Soc Chang 162. https://doi.org/10.1016/j.techfore.2020.120413

Duygan M, Kachi A, Oliveira TD, Rinscheid A (2021b) Introducing the endowment-practiceinstitutions (EPI) framework for studying agency in the institutional contestation of sociotechnical regimes. J Clean Pro 296:126396

Ebers Broughel A, Wüstenhagen R (2021) The influence of policy risk on Swiss wind power investment. In: Hettich P, Kachi A (eds) Swiss energy governance. Springer, New York

Ejderyan O, Ruef F, Stauffacher M (2019) Geothermal energy in Switzerland: highlighting the role of context. In: Manzella A, Allansdottir A, Pellizzone A (eds) Geothermal energy and society, lecture notes in energy, vol 67. Springer, Cham, pp 239-257

Gross C (2007) Community perspectives of wind energy in Australia: the application of a justice and community fairness framework to increase social acceptance. Energy Policy 35 (5):2727-2736. https://doi.org/10.1016/j.enpol.2006.12.013

Hacker JS, Pierson P (2014) After the "master theory": downs, Schattschneider, and the rebirth of policy-focused analysis. Perspect Polit 12(3):643-662. https://doi.org/10.1017/ S1537592714001637

Hall RL, Deardorff AV (2006) Lobbying as legislative subsidy. Am Polit Sci Rev 100(1):69-84. https://doi.org/10.1017/S0003055406062010

Hansla A (2011) Value orientation and framing as determinants of stated willingness to pay for eco-labeled electricity. Energ Effic 4(2):185-192. https://doi.org/10.1007/s12053-010-9096-0

Hillman AJ, Hitt MA (1999) Corporate political strategy formulation: a model of approach, participation, and strategy decisions. Acad Manag Rev 24(4):825-842

Kollman K (1998) Outside lobbying: public opinion and interest group strategies. Princeton University Press, Princeton, NJ

Levy DL, Egan D (1998) Capital contests: national and transnational channels of corporate influence on the climate change negotiations. Polit Soc 26(3):337-361. https://doi.org/10. $1177 / 0032329298026003003$

Mahoney C (2007) Lobbying success in the United States and the European Union. J Publ Policy 27 (1):35-56. https://doi.org/10.1017/S0143814X07000608

Morf P (2020) Die Stromversorgung ist gefährdet. Finanz und Wirtschaft, 27 May 2020. Available at https://www.fuw.ch

Offe C, Wiesenthal H (1980) Two logics of collective action: theoretical notes on social class and organizational form. Polit Power Soc Theory 1(1):67-115

Rinscheid A (2015) Crisis, policy discourse, and major policy change: exploring the role of subsystem polarization in nuclear energy policymaking. Eur Policy Anal 1(2):34-70

Rinscheid A, Udris L (2021) Referendum campaigns in Swiss energy policy. In: Hettich P, Kachi A (eds) Swiss energy governance. Springer, New York

Rinscheid A, Wüstenhagen R (2019) German voters would prefer a more ambitious timeline to phase out coal. Nat Energy 4(12):1016-1017

Schaffer L, Levis A (2021) Public discourses on (sectoral) energy policy in Switzerland. In: Hettich P, Kachi A (eds) Swiss energy governance. Springer, New York

Stalder H (2017) Wo Windräder wachsen werden. NZZ, 28 June 2017. Available at https://www. nzz.ch

Stigler GJ (1971) The theory of economic regulation. Bell J Econ Manage Sci 2(1):3-21

Stutzer R, Rinscheid A, Oliveira TD, Loureiro PM, Kachi A, Duygan M (2021) Black coal, thin ice: the discursive legitimisation of Australian coal in the age of climate change. Humanit Soc Sci Commun 8:178

Suisse éole (2017) Gute Gründe für Schweizer Windenergie. Liestal, 28 March 2017. Available at https://www.suisse-eole.ch 
Swiss Federal Office of Energy (2017) Wichtigste Neuerungen im Energierecht ab 2018, 2 November 2017. Available at https://www.bfe.admin.ch

Swiss Federal Office of Energy (2018a) Energiestrategie 2050 nach dem Inkrafttreten des neuen Energiegesetzes. Presentation, available at https://www.bfe.admin.ch

Swiss Federal Office of Energy (2018b) Roadmap Elektromobilität. Available at http://www. admin.ch

Tabi A, Wüstenhagen R (2017) Keep it local and fish-friendly: social acceptance of hydropower projects in Switzerland. Renew Sust Energ Rev 68(1):763-773

Varone F, Ingold KM, Jourdain C (2016) Studying policy advocacy through social network analysis. Eur Polit Sci Prev:1-15. https://doi.org/10.1057/eps.2016.16

Walker ET, Rea CM (2014) The political mobilization of firms and industries. Annu Rev Sociol 40:281-304. https://doi.org/10.1146/annurev-soc-071913-043215

Weiler F, Brändli M (2015) Inside versus outside lobbying: how the institutional framework shapes the lobbying behaviour of interest groups. Eur J Polit Res 54(4):745-766. https://doi.org/10. 1111/1475-6765.12106

Wüstenhagen R, Wolsink M, Bürer MJ (2007) Social acceptance of renewable energy innovation: an introduction to the concept. Energy Policy 35(5):2683-2691. https://doi.org/10.1016/j.enpol. 2006.12.001

Mert Duygan is Research Associate at the Faculty of Business and Economics, University of Basel, Basel, Switzerland and PostDoc at the Swiss Federal Institute of Aquatic Science and Technology (Eawag), Department of Environmental Social Sciences, Dübendorf, Switzerland.

Aya Kachi is Associate Professor for International Political Economy and Energy Policy at the Faculty of Business and Economics, University of Basel, Basel, Switzerland.

Fintan Oeri is a Ph.D. candidate at the Faculty of Business and Economics, University of Basel, Basel, Switzerland.

Thiago D. Oliveira is a former member of the Faculty of Business and Economics, University of Basel, Basel, Switzerland.

Adrian Rinscheid is International Postdoctoral Fellow and Lecturer at the Institute for Economy and the Environment, University of St. Gallen, St. Gallen, Switzerland.

Open Access This chapter is licensed under the terms of the Creative Commons Attribution 4.0 International License (http://creativecommons.org/licenses/by/4.0/), which permits use, sharing, adaptation, distribution and reproduction in any medium or format, as long as you give appropriate credit to the original author(s) and the source, provide a link to the Creative Commons license and indicate if changes were made.

The images or other third party material in this chapter are included in the chapter's Creative Commons license, unless indicated otherwise in a credit line to the material. If material is not included in the chapter's Creative Commons license and your intended use is not permitted by statutory regulation or exceeds the permitted use, you will need to obtain permission directly from the copyright holder.

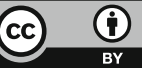

